\title{
Synthesis of a Di- $N$-cyanoethylated Tetraaza Macrocycle Containing Eight $C$-Methyl Groups and Its Nickel(II) Complex: Effects of the Methyl Groups on Their Properties
}

\author{
Shin-Geol Kang, Kiseok Ryu, and Jinkwon Kim ${ }^{\dagger}$ \\ Deparment of Chemistr. Taegu Chiversity Kumgsan 712-714. Korea \\ ${ }^{\dagger}$ Department of Chemistry, Kongiu National Liversit, Kongin $314-701$, Korea \\ Received July 10, 2001
}

\begin{abstract}
A new di- $\mathrm{N}$-cyanoethylated 14-membered tetraaza macrocycle 1.8 -bis(2-cyanoethyl)-3,5.7.7.10,12.14.14octamethyl-1.4,8,11-tetraazacyclotetradecane $\left(\mathrm{L}^{2}\right)$ and its nickel(II) complex $\left[\mathrm{NiL}^{2}(\mathrm{OAc})\right]^{-}$have been prepared. The square-planar complex $\left[\mathrm{NiL}^{2}\right]\left(\mathrm{ClO}_{4}\right)_{2}$ can be prepared by addition of $\mathrm{HClO}_{4}$ to a hot aqueous solution of $\left[\mathrm{NiL}^{*}(\mathrm{OAc})\right]^{-}$. The $\mathrm{Ni}-\mathrm{N}$ (tertiary amino group) bond distances $(2.008 \mathrm{~A})$ of $\left[\mathrm{NiL}^{-}\right]\left(\mathrm{ClO}_{4}\right)_{2}$ are relatively long, and the complex exhibits a $d$ - $d$ transition band at unusually long wavelength ( $c a .515 \mathrm{~mm}$ ). The complex $\left[\mathrm{NiL}^{-}\right]\left(\mathrm{ClO}_{4}\right)$. rapidly reacts with acetate ion or ethylenedianine (en) to produce $\left[\mathrm{NiL}^{2}(\mathrm{OAc})\right]^{+}$or $\left[\mathrm{Ni}(\mathrm{en})_{3}\right]^{\mathbf{S}^{-}}$, respectively, and is readily decomposed in $\mathrm{NaOH}(0.01 \mathrm{M})$ solution. The chenical properties of $\left[\mathrm{NiL}^{-}\right]^{3+}$ as well as its synthetic procedure are quite different from those for other related 14 -membered tetraaza macrocyclic complexes. Effects of the $\mathrm{N}$-cyanoetlyl and $C$-methyl groups on the properties of $\mathrm{L}^{2}$
\end{abstract}

Keywords : Macrocyclic compounds. Nickel(II) complexes. Cyanoethyl pendant arms. Crystal structure.

\section{Introduction}

There has been considerable interest in the preparation of various 14-membered tetraaza macrocyclic compounds containing additional $\mathrm{N}$ - and/or $\mathrm{C}$-alkyl groups because of the effects of the alkyl groups on their chemical properties and coordination geometry. ${ }^{1.16}$ In most cases. the effects of the $C$-alkyl groups are relatively weak or negligible and have received much less attention than those of the $N$-alkyl groups. However. some recent works indicate that coordination geometry and/or chemical properties of such compounds can be also affected significantly by the $C$-alkyl groups if there are additional $N$-substituents ${ }^{6.0 \mathrm{i}}$

Some 14-membered tetraaza macrocycles containing $\mathrm{N}$ cyanoethyl pendant arms. such as $\mathrm{L}^{7} \cdot \mathrm{L}^{8}$. $\mathrm{L}^{11}$. and $\mathrm{L}^{11}$, have been prepared. ${ }^{3\left({ }^{1}-13\right.}$ It has been observed that chemical reactivity of such compounds are strongly affected by the $C$ substituents. For example. although $\left[\mathrm{NiL}^{\dagger}\right]^{3+}$ can be prepared readily by the reaction of the metal ion with the macrocycle. ${ }^{11,12}$ the reaction of $\mathrm{L}^{10}$ with $\mathrm{Ni}^{\mathrm{i}^{+}+}$produces the di- $\mathrm{N}$ cyanoethy lated complex $\left.\left[\mathrm{NiL}^{11}\right]^{3+} \cdot\right]^{10}$ the complex of $\mathrm{L}^{10}$ can not be prepared by the reaction. ${ }^{11}$ The cyanoethyl pendant arms $\left(-\mathrm{CH}_{2} \mathrm{CH}_{2} \mathrm{CN}\right)$ of $\left[\mathrm{NiL}^{7}\right]^{3+}$ are slowly hydrolyzed to the corresponding amide groups $\left(-\mathrm{CH}_{2} \mathrm{CH}_{2} \mathrm{CONH}_{2}\right)$ in boiling aqueous solutions. ${ }^{11,12}$ On the other hand. $\left[\mathrm{NiL}^{11}\right]^{3+}$ is completely decyanoethylated to $\left[\mathrm{NiL}^{\mathrm{j}}\right]^{3^{+}}$before hydrolysis under similar conditions. ${ }^{i j}$ Until now the effects of $C$-substituents on the properties of $N$-cyanoethylated macrocyclic compounds are not thoroughly investigated because examples of such compounds are relatively rare. ${ }^{\text {li. } 12}$ This prompted to us to prepare the di- $N$-cyanoethylated macrocycle $\mathrm{L}^{2}$. in which eight methyl groups are attached to the carbon atoms. and its nickel(II) complexes. The nickel(II) complex of $\mathrm{L}^{\mathbb{z}}$ contain- ing six $C$-methyl groups was also prepared for comparison. The major aim of this work was to understand the effects of the $C$-alkyl groups on the reactivity and coordination behavior of the $\mathrm{N}$-cyanoethylated macrocyclic compounds Somewhat surprisingly. it was found that the synthetic procedure and reactivity of the nickel(II) complex $\left[\mathrm{NiL}^{-}\right]$ $\left(\mathrm{ClO}_{4}\right)_{2}$ as well as the ligand field strength are considerably different from those for the complexes of $\mathrm{L}^{3}, \mathrm{~L}^{4}, \mathrm{~L}^{8}$, and $\mathrm{L}^{11}$ Synthesis and properties of $\mathrm{L}^{2}$ and its nickel(II) complexes are reported. together with the crystal structure of $\left[\mathrm{NiL}^{-}\right]$ $\left(\mathrm{ClO}_{4}\right)_{2}$

\section{Experimental Section}

Measurements. Infrared spectra were recorded with a Shimadzu IR-440 spectrophotometer. electronic absorption spectra with a Shimadzu UV-160 spectrophotometer. NMR spectra with a Varian Mercury 300 NMR spectrometer. and conductance measurements with a Metrolmm Herisau Conductometer E518. Elemental analyses and mass spectral analysis were performed at the Korea Basic Science Institute. Taegu. Korea. Magnetic moments were calculated from magnetic susceptibility data obtained using a Jolnnson Matthey MK-1 magnetic susceptibility balance.

Synthesis. Safety Note: Perchlorate salts of transition metal complexes with organic ligands are often explosive and should be handled with caution.

$\mathbf{L}^{2}$. The macrocycle $\mathrm{L}^{1}$ was prepared according to the reported method ${ }^{15.16}$ To a methanol solution $(20 \mathrm{~mL})$ of $\mathrm{L}^{1}$ (3.0 g. $\left.9.7 \times 10^{-3} \mathrm{~mol}\right)$ was added an excess of acrylonitrile $\left(2.4 \mathrm{~mL} .7 .5 \times 10^{-2} \mathrm{~mol}\right)$. The mixture was stirred for $c a .30$ $\mathrm{h}$ at room temperature. The resulting solution was evaporated at room temperature to produce the white solid. The 

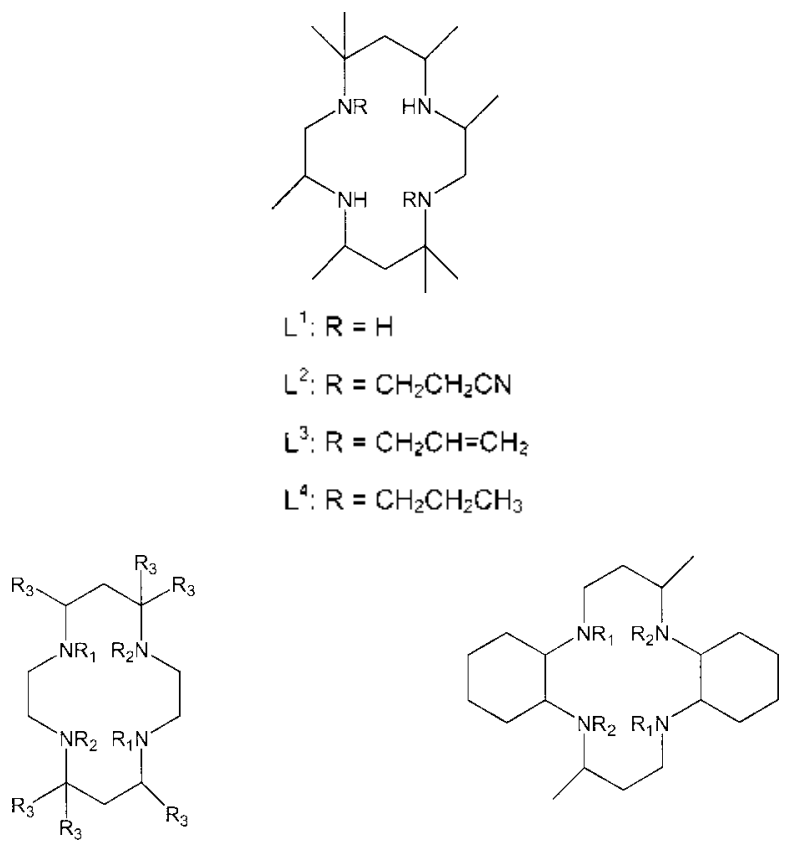

$$
\begin{array}{ll}
L^{5}: R \cdot=R_{2}=R_{3}=H & L^{9}: R_{1}=R_{2}=H \\
L^{5}: R \cdot=R_{2}=H ; R_{3}=M e & L^{10}: R_{1}=R_{2}=C_{2} C_{2} H_{2} C N \\
L^{7}: R \cdot=R_{2}=C_{2} C H_{2} C N ; R_{3}=H & L^{11}: R_{1}=C_{2} C H_{2} C N ; R_{2}=H \\
L^{8}: R:=C_{2} H_{2} H_{2} C N ; R_{2}=H ; R_{3}=M e &
\end{array}
$$

solid was filtered. washed with diethyl ether, and dried in air. Yield: $\sim 80 \%$. Anal. Calcd for $\mathrm{C}_{24} \mathrm{H}_{46} \mathrm{~N}_{6}$ : C, 68.85; $\mathrm{H}, 11.07$, N. $20.07 \%$. Found: C. $68.63 ;$ H. $11.17 ;$ N. $20.17 \%$. Mass $(m z): 419\left(\mathrm{M}^{+}\right)$. IR $\left(\mathrm{cm}^{-1}\right): 3235(\mathrm{vN}-\mathrm{H})$ and $2250(\mathrm{KCN})$. ${ }^{13} \mathrm{C}-\mathrm{NMR}\left(\mathrm{CDCl}_{3}\right): \delta 18.8(\mathrm{Me}), 20.8(\mathrm{Me}), 21.0(\mathrm{Me}), 22.8$ $(\mathrm{Me}), 28.0,45.5,46.5,47.3,47.7,56.9,58.4$, and $120.7(\mathrm{CN})$ ppm.

[NiL $\left.{ }^{2}(\mathbf{O A c})\right] \mathrm{ClO}_{4}$. A methanol solution $(20 \mathrm{~mL})$ of $\mathrm{Ni}(\mathrm{OAc})_{2} \cdot 4 \mathrm{H}_{2} \mathrm{O}(2.0 \mathrm{~g}, 8.0 \mathrm{mmol})$ and $\mathrm{L}^{2}(2.0 \mathrm{~g} .4 .8 \mathrm{mmol})$ was refluxed for $c a$. $1 \mathrm{hr}$. An excess of $\mathrm{NaClO}_{4}$ was added to the solution at room temperature. then a green solid was precipitated. The product was filtered. washed with methanol and recrystallized from a $1.0 \times 10^{-3} \mathrm{M} \mathrm{NaOAc} \mathrm{MeCN}-$ water $(2: 1)$ mixture. Yield: $\sim 80 \%$. Anal. Calcd for $\mathrm{C}_{36} \mathrm{H}_{99-}$ $\mathrm{N}_{6} \mathrm{NiCl}_{2} \mathrm{O}_{6}:$ C. 49.11: H. 7.77: N. 13.22\%. Found: C. 50.05: H. 8.23: N. $13.54 \%$. IR $\left(\mathrm{cm}^{-1}\right): 3225(v \mathrm{~N}-\mathrm{H}) .3165(\mathrm{vN}-\mathrm{H})$. $2250(v \mathrm{CN})$ ) and $1600(v \mathrm{CO})$. FAB mass $(m z)$ : 535 ([M$\left.\left.\mathrm{ClO}_{4}\right]^{+}\right)$and $476\left(\left[\mathrm{M}-\mathrm{ClO}_{4}-\mathrm{CH}_{3} \mathrm{COOH}\right]^{+}\right)$. Magnetic moment $\left(\mu_{\mathrm{eff}}\right): 2.65 \mu_{\mathrm{B}}$ at $20^{\circ} \mathrm{C}$.

$\left[\mathrm{NiL}^{2}\right]\left(\mathrm{ClO}_{4}\right)_{2}$. To a warm acetonitrile solution $(10 \mathrm{~mL})$ of $\left[\mathrm{NiL}^{2}(\mathrm{OAc})\right] \mathrm{ClO}_{4}(0.5 \mathrm{~g})$ was added water $(20 \mathrm{~mL})$. The volume of the solution was reduced to $c a .20 \mathrm{~mL}$ on a hot water bath $\left(70-80^{\circ} \mathrm{C}\right)$, and $\mathrm{pH}$ of the resulting solution was adjusted to $\mathrm{ca} .3 .0$ by dropping $1.0 \mathrm{M} \mathrm{HClO}_{4}$. The solution. which was initially green turned intense orange-red. After the resulting solution had been heated on the water bath for ca. 5 min. concentrated $\mathrm{HClO}_{4}$ (2-3 drops) and $\mathrm{NaClO}_{4}$ (excess) were added at room temperature to produce the red crystal. The product was filtered. washed with methanol. and recrystallized from DMSO-water $(1: 1)$ mixture. Yield: $-60 \%$. Anal. Calcd for $\mathrm{C}_{24} \mathrm{H}_{45} \mathrm{~N}_{6} \mathrm{NiCl}_{2} \mathrm{O}_{8}:$ C. $42.63 ; \mathrm{H}$. 6.86; N, $12.43 \%$. Found: C, $42.29 ;$ H. $6.93: \mathrm{N}, 12.28 \%$. IR $\left(\mathrm{cm}^{-1}\right)$ : $3140(v \mathrm{~N}-\mathrm{H})$ and $2250(\mathrm{KCN})$.

$\left[\mathrm{H}_{2} \mathrm{~L}^{2}\right]\left(\mathrm{ClO}_{4}\right)_{2}$. The addition of an excess $\mathrm{HClO}_{4}$ to a acetonitrile-water solution of $\left[\mathrm{NiL}^{2}(\mathrm{OAc})\right] \mathrm{ClO}_{4}$ at room temperature produced a white solid. The product was filtered. washed with methanol, and dried in air. Anal. Calcd for $\mathrm{C}_{24} \mathrm{H}_{48} \mathrm{~N}_{6} \mathrm{Cl}_{2} \mathrm{O}_{8}:$ C. 46.68: H. 7.51; N, 13.61\%. Found: $\mathrm{C}$, 45.94: H. 7.56: N. $13.55 \%$. The compound was also obtained by the addition of $\mathrm{HClO}_{4}$ to the reaction mixture of $\mathrm{L}^{2}$ and $\mathrm{NiCl}_{2} \cdot 6 \mathrm{H}_{2} \mathrm{O}$ in methanol.

$\left[\mathrm{NiL}^{8}\right]\left(\mathrm{ClO}_{4}\right)_{2}$. The macrocycle $\mathrm{L}^{8}$ was prepared according to the reported method. ${ }^{13}$ A methanol solution $(20 \mathrm{~mL})$ of $\mathrm{Ni}(\mathrm{OAC})=4 \mathrm{H}_{2} \mathrm{O}(1.3 \mathrm{~g} .5 .1 \mathrm{mmol})$ and $\mathrm{L}^{8}(1.5 \mathrm{~g} .3 .8$ mmol) was refluxed for $c a .30 \mathrm{~min}$. An excess of $\mathrm{HClO}_{4}$ was added to the solution. and then the orange-red solid was precipitated. The product was filtered, washed with methanol, and recrystallized from acetonitrile-water $(2 ; 1)$ mixture. Yield: $-80 \%$. Anal. Calcd for $\mathrm{C}_{2} \mathrm{H}_{4} \mathrm{~N}_{6} \mathrm{NiCl}_{2} \mathrm{O}_{8}$ : C, 40.76: H, 6.53: N. $12.96 \%$. Found: C, 40.89; H. 6.78; N, $13.07 \%$. IR $\left(\mathrm{cm}^{-1}\right): 3165(\mathrm{VN}-\mathrm{H})$ and $2250(\mathrm{l} \mathrm{CN})$.

Crystal Structure Determination. An red crystal of $\left[\mathrm{NiL}^{-}\right]\left(\mathrm{ClO}_{4}\right)_{2}$, obtained from $\mathrm{DMSO} / \mathrm{H}_{2} \mathrm{O}$ solution. was mounted on a thin glass fiber. Intensity data were collected on an Enraf-Nonius CAD4 Diffractometer. Unit cell parameters were determined from a least-squares fit of 25 accurately centered reflections $(20<2 \theta<32)$. Data were collected at $293 \mathrm{~K}$ and were corrected for Lorentz and

\begin{tabular}{|c|c|}
\hline Formula & $\mathrm{C}_{24} \mathrm{H}_{4 \times} \mathrm{Cl}_{2} \mathrm{~N}_{4} \mathrm{NiO}_{8}$ \\
\hline M & 676.28 \\
\hline Cryst size $(\mathrm{mm})$ & $0.4 \times 0.4 \times 0.3$ \\
\hline Space group & $P 2_{1} / n$ \\
\hline$a(A)$ & $9.571(2)$ \\
\hline$b(\AA)$ & $11.079(2)$ \\
\hline$c(\AA)$ & $14.232(3)$ \\
\hline$\beta(\times)$ & $92.1+(2)$ \\
\hline$V^{*}\left(\AA^{3}\right)$ & $1508.1(5)$ \\
\hline$Z$ & 2 \\
\hline$D_{\mathrm{c}}\left(\mathrm{g} \mathrm{cm}^{-3}\right)$ & 1.489 \\
\hline$\mu / \mathrm{cm}^{-1}$ & 8.76 \\
\hline Range of transmission factor & $84.51-99.98 \%$ \\
\hline Scan mode & $\omega-2 \theta$ \\
\hline No. of unique reflections & 2651 \\
\hline No. of observed reflections & $2215\left(I_{0}>2 \sigma\left(I_{0}\right)\right)$ \\
\hline $2 \theta \max /{ }^{\circ}$ & 50 \\
\hline No. of parameters refined & 187 \\
\hline $\mathrm{R} 1, \mathrm{wR} 2^{*}, \mathrm{GOF}$ & $0.0370,0.1005,1.05$ \\
\hline
\end{tabular}
polarization effects. Empirical $\Psi$ absorption correction was applied. The SHELXS-86 program was utilized for the heavy atom method. ${ }^{17}$ The structure refinements were performed with the SHELXL-93 program on $\mathrm{F}^{2}$ data. ${ }^{18}$ Heavy atoms ( $\mathrm{Ni}$ and $\mathrm{Cl}$ ) were located by use of heavy atom method.

Table 1. Crystal and Refinement Data for $\left[\mathrm{NiL}^{2}\right]\left(\mathrm{ClO}_{4}\right)$ s

$\omega=1:\left[\sigma^{2}\left(F_{o}{ }^{2}\right)-(0.0565 P)^{2}+1.8617 P\right]$ where $P=\left(F_{o}{ }^{2}-2 F_{i}{ }^{2}\right) 3$ 
Other non-hydrogen atoms were found from successive difference Fourier synthesis. Anisotropic thermal parameters for all non-hydrogen atoms were included in the refinements. All hydrogen atoms bonded to carbon atoms were included in calculated positions. This $\mathrm{C}$ - $\mathrm{H}$ bond distance was fixed and $U$ values were assigned based approximiately on the $\mathrm{U}$ value of the attached atom. The other hydrogens $(\mathrm{N}-\mathrm{H})$ were included in located positions with $\mathrm{U}=0.05 \mathrm{~A}^{2}$. A final difference Fourier map revealed several random features $\left(<0.56 \mathrm{eA}^{-3}\right)$. Crystal and refinement data of the complex are summarized in Table 1.

\section{Results and Discussion}

Synthesis and Characterization. The only product prepared from the reaction of $\mathrm{L}^{3}$ with excess acrylonitrile in methanol was the di- $N$-cyanoethylated macrocycle $\mathrm{L}^{2}$. Such a di- $N$-cyanoethylation has been also observed for the reaction of $\mathrm{L}^{7}$ with excess acry lonitrile. ${ }^{13}$ However, present result is different from the fact that the tetra- $N$-cyanoethylated macrocycle $\mathrm{L}^{11}$ as well as $\mathrm{L}^{11}$ can be prepared readily by the reaction of $\mathrm{L}^{9}$ with acrylonitrile under the sinilar condition. ${ }^{\text {li }}$ The macrocycle $\mathrm{L}^{2}$ dissolves in chloroform but slightly in methanol at room temperature. The mass, infrared, and ${ }^{13} \mathrm{C}$-NMR spectral data of the compound are listed in the Experimental. The position of the cyanoethyl pendant arms was confirmed by the crystal structure of $\left.\left[\mathrm{NiL}^{\hat{2}}\right]\left(\mathrm{ClO}_{4}\right)\right)_{2}$ (see below)

The reaction of $\mathrm{L}^{8}$ with $\mathrm{Ni}(\mathrm{OAc})_{2} \cdot \mathrm{H}_{2} \mathrm{O}$ followed by addition of $\mathrm{NaClO}_{4}$ produced the square-planar complex $\left[\mathrm{NiL}^{8}\right]\left(\mathrm{ClO}_{4}\right)_{2}$. The similar reaction of $\mathrm{L}^{2}$ with $\mathrm{Ni}(\mathrm{OAc})_{2}$. $4 \mathrm{H}_{2} \mathrm{O}$ produced only the green complex $\left[\mathrm{NiL}^{2}(\mathrm{OAc})\right] \mathrm{ClO}_{4}$. in which the acetate ion is coordinated to the metal ion. The square-planar complex $\left[\mathrm{NiL}^{2}\right]\left(\mathrm{ClO}_{4}\right)_{2}$ can be prepared by adding $\mathrm{HClO}_{4}$ to a hot aqueous solution of $\left[\mathrm{NiL}^{3}(\mathrm{OAc})\right]$ $\mathrm{ClO}_{4}$. As described in Experimental, however. the reaction conditions such as $\mathrm{pH}$ and temperature must be carefully controlled for the preparation of the square-planar complex. For example. addition of $\mathrm{HClO}_{4}$ to the solution of $\mathrm{NiL}^{2}$ $(\mathrm{OAc})] \mathrm{ClO}_{4}$ at room temperature produces the white salt $\left[\mathrm{H}_{2} \mathrm{~L}^{2}\right]\left(\mathrm{ClO}_{4}\right)_{2}$. It should be noted that the complex $\left[\mathrm{NiL}^{2}\right]$ $\left(\mathrm{ClO}_{4}\right)_{2}$ could not be prepared by direct reaction of $\mathrm{L}^{2}$ with $\mathrm{Ni}^{2-}$ ion. Addition of $\mathrm{NaClO}_{4}$ to a methanol solution (reflux $>3 \mathrm{~h}$ ) of the macrocycle and hydrated or dehydrated $\mathrm{NiX}_{2}(\mathrm{X}$ $=\mathrm{CH}_{3} \mathrm{COO}^{-}, \mathrm{Cl}^{-}$, or $\left.\mathrm{NO}_{3}{ }^{-}\right)$produced only $\left[\mathrm{NiL}^{2}(\mathrm{OAc})\right] \mathrm{ClO}_{4}$ or $\left[\mathrm{H}_{2} \mathrm{~L}^{-}\right]\left(\mathrm{ClO}_{4}\right)_{2}$. Present result is quite different from those reported for most other di- $N$-substituted 14 -membered tetraaza macrocycles, ${ }^{79.101 .19}$ the square-planar complexes $[\mathrm{NiL}]$ $\left(\mathrm{ClO}_{4}\right)_{2}\left(\mathrm{~L}=\mathrm{L}^{3} . \mathrm{L}^{4} . \mathrm{L}^{8}\right.$. or $\left.\mathrm{L}^{11}\right)$ can be prepared readily by direct reaction of each macrocycle with hydrated or dehydrated $\mathrm{Ni}^{2+}$ ion.

The complexes $\left[\mathrm{NiL}^{2}(\mathrm{OAc})\right] \mathrm{ClO}_{4}$ and $\left[\mathrm{NiL}^{2}\right]\left(\mathrm{ClO}_{4}\right)_{2}$ are soluble in nitromethane and dimethylsulfoxide. Infrared. ${ }^{13} \mathrm{C}-\mathrm{NMR}$. and/or FAB-mass spectra of the complexes are summarized in Experimental. together with elemental analyses. The molar conductance values of $\left[\mathrm{NiL}^{2}(\mathrm{OAc})\right] \mathrm{ClO}_{4}$ $\left(85 \Omega^{-1} \mathrm{~mol}^{-1} \mathrm{~cm}^{-}\right)$and $\left[\mathrm{NiL}^{-}\right]\left(\mathrm{ClO}_{4}\right)_{2}\left(140 \Omega^{-1} \mathrm{~mol}^{-1} \mathrm{~cm}^{-}\right)$
Table 2. Electronic Absorption Spectral Data"

\begin{tabular}{|c|c|}
\hline Complex & $\lambda_{\text {trax }}, \mathrm{nm}\left(\varepsilon, \mathrm{M}^{-1} \mathrm{~cm}^{-1}\right)$ \\
\hline$\left[\mathrm{NiL}^{b}\right]\left(\mathrm{ClO}_{4}\right)_{2}{ }^{b}$ & $469(83)$ \\
\hline \multirow[t]{2}{*}[\mathrm{NiL}^{-}(\mathrm{OAc})]{$\mathrm{ClO}_{+}$} & $4(06(61) 705(24)$ \\
\hline & $405(50)^{\circ} 695(20)^{\circ}$ \\
\hline$\left[\mathrm{NiL}^{-}\right]\left(\mathrm{ClO}_{4}\right)_{2}$ & $515(150) 518(145)^{d}$ \\
\hline$\left[\mathrm{NiL}^{3}\right]\left(\mathrm{ClO}_{4}\right)_{2}{ }^{0}$ & $505(120) 506(118)^{c}$ \\
\hline$\left[\mathrm{NiL}^{-1}\right]\left(\mathrm{ClO}_{4}\right)_{2}{ }^{b}$ & $502(110) 502(112)^{c}$ \\
\hline$\left[\mathrm{NiL}^{8}\right]\left(\mathrm{ClO}_{4}\right)_{2}$ & $496(120)+95(115)^{c}$ \\
\hline$\left[\mathrm{NiL}^{11}\right]\left(\mathrm{ClO}_{4}\right)_{2}{ }^{*}$ & $490(117)+90(115)^{c}$ \\
\hline
\end{tabular}

"In nitromethane at $20{ }^{\circ} \mathrm{C}$ unless otherwise specified. "Ref. 9. 'In acetonitrile. 'In dimethylsul foxide. 'Ref. 10 .

measured in nitromethane indicate that the complexes are $1: 1$ and $1: 2$ electrolytes, respectively.

In the electronic absorption spectra (Table 2), the $d-d$ band of $\left[\mathrm{NiL}^{-}\right]\left(\mathrm{ClO}_{4}\right)_{2}$ is observed at much longer wavelength than that of $\left[\mathrm{NiL}^{1}\right]\left(\mathrm{ClO}_{4}\right)_{2}$. as usual. Interestingly. the wavelengths of the di- $N$-cyanoethylated macrocyclic complexes are strongly affected by the number or type of the $C$ substituents and show the order $\mathrm{L}^{11}(490 \mathrm{~nm})<\mathrm{L}^{8}(c a .495)$ $<\mathrm{L}^{2}(c a .515 \mathrm{~nm})$. Furthermore. the wavelength of $\left[\mathrm{NiL}^{-}\right]$ $\left(\mathrm{ClO}_{4}\right)_{2}$ is also $\mathrm{ca}$. $10 \mathrm{~mm}$ longer than those for the complexes of $\mathrm{L}^{3}$ and $\mathrm{L}^{4}$ containing two $\mathrm{N}$-alkyl groups. To our knowledge. $\left[\mathrm{NiL}^{\hat{2}}\right]\left(\mathrm{ClO}_{4}\right)_{2}$ is a rarely prepared di $-\mathrm{N}$ substituted 14-membered tetraaza macrocyclic nickel(II) complex that show the $d-d$ band at such a long wavelength $(>510 \mathrm{~mm})$. The weaker ligand strength of $\left[\mathrm{NiL}^{2}\right]\left(\mathrm{ClO}_{4}\right)$, compared to that of $[\mathrm{NiL}]\left(\mathrm{ClO}_{4}\right)_{2}\left(\mathrm{~L}=\mathrm{L}^{3} . \mathrm{L}^{+}, \mathrm{L}^{8}\right.$. or $\left.\mathrm{L}^{11}\right)$, may be attributed to the weaker $\mathrm{Ni}-\mathrm{N}$ interactions due to the severe steric crowding caused by the presence of the eight $C$-methyl groups together with the $N$-cyanoethyl pendant amms. ${ }^{3-5,7-11 i}$ The spectra of $\left[\mathrm{NiL}^{2}(\mathrm{OAc})\right] \mathrm{ClO}_{4}$ measured in nitromethane or acetonitrile show two bands at $c a .405$ and $700 \mathrm{~nm}$. which are comparable with those of various fivecoordinate nickel(II) complexes. ${ }^{2 i j \cdot 2.2}$ Unfortunately. we could not grow single crystals of $\left[\mathrm{NiL}^{2}(\mathrm{OAc})\right] \mathrm{ClO}_{4}$ suitable for the $\mathrm{X}$-ray work. and coordination geometry of the complex is not clearly understood at this point.

Crystal Structure of $\left[\mathrm{NiL}^{2}\right]\left(\mathrm{ClO}_{4}\right)_{2}$. The structure (Figure 1) of $\left[\mathrm{NiL}^{2}\right]^{3+}$ shows that the complex has a square-planar coordination geometry with an inversion center at the metal atom. The cyanoethyl groups are not involved in the coordination. The six-membered chelate rings have a chair conformation, and the five-membered chelate rings a gatche one. The macrocyclic ligand adopts the trans-III conformation.

Selected bond distances and angles of the complex are listed in Table 3. The N-Ni-N bond angle ( $\left.86.6(2)^{\circ}\right)$ involved in the five-membered chelate ring is smaller than that $\left(93.4(2)^{\circ}\right)$ in the six-membered chelate ring, as usual. The $\mathrm{C}(10)-\mathrm{N}(2)-\mathrm{Ni}$ angle is $100.4(2)^{\circ}$. The $\mathrm{C}(4)-\mathrm{N}(2)-\mathrm{C}(10)$ angle $\left(114.0(2)^{\circ}\right)$ is larger than the $\mathrm{C}(3)-\mathrm{N}(2)-\mathrm{C}(10)$ angle. The N(3)-C(12) bond distance (1.13I(5) $\AA)$ is corresponding to the triple bond. The $\mathrm{Ni}-\mathrm{N}(\mathrm{l})$ (secondary) and $\mathrm{Ni}-\mathrm{N}(2)$ (tertiary) distances (1.972(2) and $2.008(2) \dot{A}$. respectively) are comparable with those of the square-planar complex 


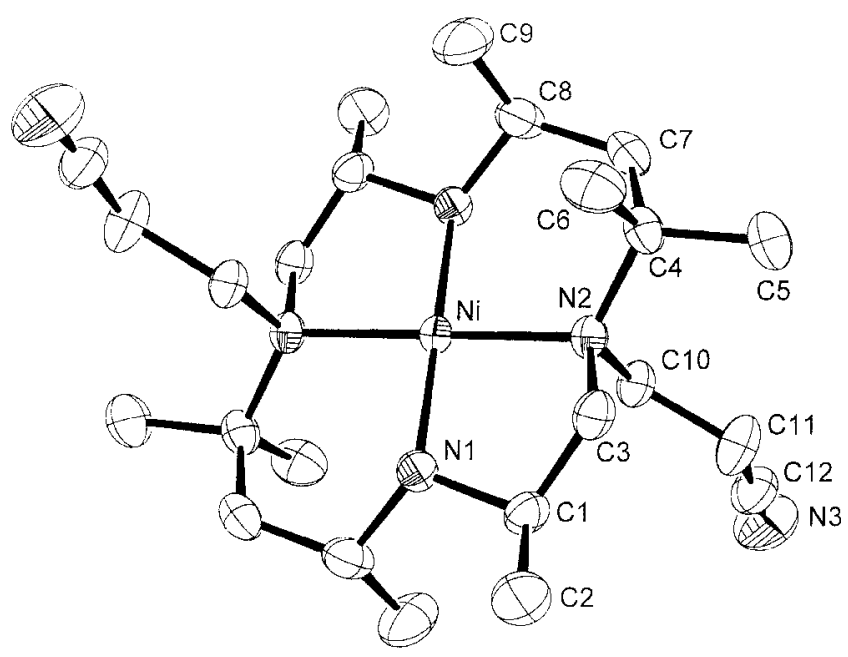

Figure 1. An ORTEP diagram of $\left[\mathrm{NiL}^{\underline{2}}\right]^{\underline{2}+}$ in $\left[\mathrm{NiL}^{\underline{2}}\right]\left(\mathrm{ClO}_{4}\right)_{2}$.

$\left[\mathrm{NiL}^{3}\right]\left(\mathrm{ClO}_{4}\right) \leq(1.984(2) \text { and } 2.000(2) \AA)^{9}$ but are distinctly longer than those of other related nickel(II) complexes with di- $N$-alkylated 14-membered tetraaza macrocycles. ${ }^{57}$ One of the interesting structural features of the complex is that the $\mathrm{Ni}-\mathrm{N}(2)$ distance is much longer than the $\mathrm{Ni}-\mathrm{N}(1)$ distance. The $\mathrm{N}(2)-\mathrm{C}(4)$ distance $(1.549(3) \mathrm{A})$ is also considerably longer than other $\mathrm{N}-\mathrm{C}$ single bond distances. The relatively long $\mathrm{Ni}-\mathrm{N}(2)$ and $\mathrm{N}(2)-\mathrm{C}(4)$ distances may be resulted from the severe steric crowding caused by both the metlyl groups at the $\mathrm{C}(4)$ atom and the $N$-cyanoethyl groups. The cry stallographic study shows that the unusually weak ligand field of the complex is correlated with the long $\mathrm{Ni}-\mathrm{N}(2)$ distance.

Solution Behaviors. The complex $\left[\mathrm{NiL}^{3}\right]\left(\mathrm{ClO}_{4}\right)_{2}$ is relatively stable in neutral and acidic aqueous solutions at room temperature. Electronic absorption spectra of the complex $\left(3.0 \times 10^{-\hat{3}} \mathrm{M}\right)$ measured in $0.1 \mathrm{M} \mathrm{HClO}_{4}$ aqueous solution indicated that no apparent decomposition of the complex or decyanoethylation takes place in $20 \mathrm{~h}$ at $25^{\circ} \mathrm{C}$. On the other hand, the complex was completely decyanoethylated to $\left[\mathrm{NiL}^{1}\right]^{2^{-}}$within $3 \mathrm{~h}$ in boiling aqueous solution. Such behaviors are not so much different from those observed for $\left[\mathrm{NiL}^{8}\right]^{--}$and $\left[\mathrm{NiL}^{11}\right]^{2+}$ in neutral or acidic aqueous solutions. ${ }^{10.15}$

In a DMSO-water $(1: 1)$ solution containing $\mathrm{NaOAc}(0.1$

Table 3. Selected Bond Distances ( $\AA$ ) and angles (deg) of $\left[\mathrm{NiL}^{2}\right]\left(\mathrm{ClO}_{4}\right)_{2}$

\begin{tabular}{llll}
\hline $\mathrm{Ni}-\mathrm{N}(1)$ & $1.972(2)$ & $\mathrm{Ni}-\mathrm{N}(2)$ & $2.008(2)$ \\
$\mathrm{N}(1)-\mathrm{C}(1)$ & $1.502(3)$ & $\mathrm{N}(2)-\mathrm{C}(3)$ & $1.494(3)$ \\
$\mathrm{N}(2)-\mathrm{C}(4)$ & $1.549(3)$ & $\mathrm{N}(2)-\mathrm{C}(10)$ & $1.511(3)$ \\
$\mathrm{N}(3)-\mathrm{C}(12)$ & $1.131(5)$ & $\mathrm{C}(1)-\mathrm{C}(3)$ & $1.487(4)$ \\
$\mathrm{C}(10)-\mathrm{C}(11)$ & $1.536(4)$ & $\mathrm{C}(11)-\mathrm{C}(12)$ & $1.452(5)$ \\
& & & \\
$\mathrm{N}(1)-\mathrm{Ni}-\mathrm{N}(2)$ & $86.6(2)$ & $\mathrm{N}(1)-\mathrm{Ni}-\mathrm{N}(2)$ & $93.4(2)$ \\
$\mathrm{N}(3)-\mathrm{C}(12)-\mathrm{C}(11)$ & $179.2(4)$ & $\mathrm{C}(10)-\mathrm{C}(11)-\mathrm{C}(12)$ & $108.9(3)$ \\
$\mathrm{C}(4)-\mathrm{N}(2)-\mathrm{Ni}$ & $117.7(2)$ & $\mathrm{C}(1)-\mathrm{N}(1)-\mathrm{Ni}$ & $110.1(2)$ \\
$\mathrm{C}(10)-\mathrm{N}(2)-\mathrm{Ni}$ & $100.4(2)$ & $\mathrm{C}(3)-\mathrm{N}(2)-\mathrm{C}(10)$ & $111.2(2)$ \\
$\mathrm{C}(4)-\mathrm{N}(2)-\mathrm{C}(10)$ & $114.0(2)$ & & \\
\hline
\end{tabular}

M). $\left[\mathrm{NiL}^{\hat{3}}\right]\left(\mathrm{ClO}_{4}\right)$ ) rapidly reacts with acetate ion to form the green complex $\left[\mathrm{NiL}^{-}(\mathrm{OAc})\right] \mathrm{ClO}_{4}$ even at room temperature. This was confirmed by the observation that electronic absorption spectrum of the solution was essentially the same as that of $\left[\mathrm{NiL}^{2}(\mathrm{OAc})\right] \mathrm{ClO}_{4}$. Addition of $\mathrm{NaClO}_{4}$ to the solution also produced the green complex. On the other hand. addition of a slightly excess amount of ethylenediamine (en) to a DMSO or DMSO-ivater $(1: 1)$ solution of $\left[\mathrm{NiL}^{2}\right]\left(\mathrm{ClO}_{4}\right)_{2}$ produced $\mathrm{L}^{2}$ and $\left[\mathrm{Ni}(\mathrm{en})_{3}\right]\left(\mathrm{ClO}_{4}\right)_{2}$, indicating that the macrocyclic ligand is substituted by en. The complex $\left[\mathrm{NiL}^{2}\right]\left(\mathrm{ClO}_{4}\right)$ ) was decomposed rapidly to yield $\mathrm{L}^{2}$ in a DMSO-water (1:1) solution containing $\mathrm{NaOH}$ (ca. $0.01 \mathrm{M}$ ). The substitution and addition reactions (Eqs. (I) and (2). respectively) were too fast to measure with ordinary spectroscopic methods even at room temperature. Interestingly. such behaviors are in sharp contrast to the generally observed trend that most square-planar nickel(II) complexes of 14-membered tetraaza macrocycles are quite stable and are hardly attacked by en or acetate ion at room temperature. ${ }^{10.19 .23}$ Although $\left[\mathrm{NiL}^{2}\right]^{3+}$ and $\left[\mathrm{NiL}^{4}\right]^{\hat{2}+}$ are decomposed in $\mathrm{NaOH}$ solutions, ${ }^{8}$ they do not react with acetate ion even in $>1.0 \mathrm{M} \mathrm{NaOAc}$ solutions. Present result is also different from the observation that $\left[\mathrm{NiL}^{8}\right]^{3+}$ and $\left[\mathrm{NiL}^{11}\right]^{\hat{i}^{-}}$are not decomposed even at $0.1 \mathrm{M} \mathrm{NaOH}$ solutions but are rapidly decyanoetlyylated to $\left[\mathrm{NiL}^{8}\right]^{\hat{2}^{-}}$or $\left[\mathrm{NiL}^{y}\right]^{\hat{2}-1}{ }^{10.19}$ The enhanced lability of $\left[\mathrm{NiL}^{\hat{2}}\right]\left(\mathrm{ClO}_{4}\right)_{2}$ in the solutions of $\mathrm{NaOAc}$, en, $\mathrm{NaOH}$ can be attributed to the relatively long $\mathrm{Ni}-\mathrm{N}(2)$ distance.

$$
\begin{gathered}
{\left[\mathrm{NiL}^{\hat{2}}\right]^{2+}+3 \mathrm{en} \rightarrow\left[\mathrm{Ni}(\mathrm{en})_{2}\right]^{2^{2-}}+\mathrm{L}^{2}} \\
{\left[\mathrm{NiL}^{2}\right]^{2+}+\mathrm{NaOAC} \rightarrow\left[\mathrm{NiL}^{\hat{2}}(\mathrm{OAC})\right]^{-}}
\end{gathered}
$$

In general, both the electronic and steric effects are important factors affecting the Lewis basicity and coordination behavior of alkyl amines. However. the relatively weak Ni$\mathrm{N}$ interaction and the unusual reactivity of $\left[\mathrm{NiL}^{2}\right]^{2-}$ correspond to the suggestion that the electronic effects are exceeded by the back strain of the tertiary amino groups caused by the steric repulsion between the $N$-cyanoethyl pendant arms and proximate $C$-methyl groups. ${ }^{7-1(!)}$

\section{Conclusion}

The di- $N$-cyanoethylated macrocycle $\mathrm{L}^{2}$ and its nickel(II) complexes $\left[\mathrm{NiL}^{2}(\mathrm{OAc})\right] \mathrm{ClO}_{4}$ and $\left[\mathrm{NiL}^{-}\right]\left(\mathrm{ClO}_{4}\right)_{2}$ were prepared. The square-planar complex $\left[\mathrm{NiL}^{2}\right]^{2+}$. which can be prepared by addition of $\mathrm{HClO}_{4}$ to a hot solution of $\mathrm{NiL}^{-}=$ $(\mathrm{OAc}) \mathrm{ClO}_{4}$. exhibits unusually weak ligand field strength and rapidly reacts with acetate ion or en even at room temperature. The synthetic procedure, ligand field strength, and reactivity of $\left[\mathrm{NiL}^{2}\right]^{2-}$ are distinctly different from those of $\left[\mathrm{NiL}^{3}\right]^{2+} .\left[\mathrm{NiL}^{8}\right]^{2+}$, or $\left[\mathrm{NiL}^{11}\right]^{2+}$. showing that they are strongly affected by the steric repulsion between $N$-cyanoethyl groups and proximate $(-m e t h y l$ groups

Acknowledgment. This work was supported by the Korea Research Foundation Grant (2000-015-DP0220). 


\section{References}

1. (a) Springborg, I.: Olsen, C. E.: Sotofte, I. Acta Chenica Scand. 1995. 19. 555: (b) Weisman. G. R.: Rogers. M. E.: Wong. E. S.: Jasinski. J. P.: Paight. E. S. J. Am. Chent. Soc. 1990. H12.8604.

2. (a) Zilbermann. I.: Golub. G.: Cohen. H.: Meystein. D. J. Chent. Soc. Dallon Trans. 1997. 141: (b) Golub. G.: Cohen. H: Meverstein. D. J. Chem. Soc. Chem. Conmm. 1992. 397.

3. (a) Wagner. F: Barefield. E. K. Lhorg. Chem. 1976, 15. 408; (b) Barefield. E. K. Wagner. F. Ihorg Chem. 1973. 12.2435

4. (a) Baretield. E. K.: Freeman. G. M.: Derveer. D. G. V. Ihorg. Chem. 1986. 25. 552: (b) Nakani. B. S.: Welsh. J. J. B.: Hancock. R. D. Inorg. Chem. 1983. 22. 2956: (c) Maderski, C. M.: Michael. I. P. Hancock R. D. horg. Chem. 1984. $23,1487$.

5. Chapman, I.: Ferguson. G: Gallagher I. F: Jennings, M. C: Parker. D. J. Chemt. Soc. Dalton Trants. 1992. 345.

6. Kang. S.-G.: Song. J.: Jeong. J. H. Inorg. Chim Acta 2000. 310. 196

7. Kang, S.-G.: Kim. M.-S: Whang, D: Kim, K. Inorg thim. Acta $1998,279,238$

8. Kang. S.-G.: Kim. M.-S.: Choi. I.S: Cho, M. H. Pohtredron 1995. 14. 781 .

9. Kang. S.-G.: Song. J.: Whang. D.: Kim. K. Bull. Korean Chent. Soc. 2000. 21. 1106

10. Kang. S.-G.: Rvu K. Buh. Norean Chem. Soc. 2000. 21,535
11. Wainwright, K. P. J. Chem. Soc., Dalton Trans. 1980. 2117.

12. Freemant. G. M.: Barefield. E. K.: Derveer. D. G. V. Inorg. Chent. 1984. 23.3092.

13. Aneetha. H.: Lai. Y.-H.: Lin. S.-C.: Panneerselvam. K.: Lu. T.-H.: Chung C.-S. J. Chem. Soc. Dalon Trans. 1999. 2885.

14. (a) Suh. M. P.: Shim. B. Y.; Yoon, T.-S. Horg. Chem. 1994, 33. 5509: (b) Hay. R. W. Bembi. R. Inorg. Chim. Acta 1982. 65. L227.

15. Bembi. R.: Sondhi. S. M.: Singh. A. K.: Jhanji. A. K.: Roy. T. G.: Lowi1. J. W.: Ball. R. G. Bull. Chem. Soc. Japon 1989. 62. 3701 .

16. Ito. T., Busch. D. H. J. Am Chem Soc. 1973. 95. 7528.

17. Sheldrick, G. M. SHELIS-86 User Guides, Crystallographic Department. University of Gottinggen: Germanv: 1985.

18. Sheldrick. G. M. SHELAS-93 Eser Gnides: Crystallographic Department. University of Gottinggen. Germany: 1993.

19. Kang. S.-G.: Ryu. K. Unpublished results.

20. Alcock. N. W. Balakrishnan, K. P. Moore, P.; Pike, G. A. d. Chem. Soc. Dalton Trans. 1987,889

21. Micheloni. M.: Paoletti, P.: Burki, S.: Kaden, T. Helv Chim Acto 1982. 65.587

22. Oberholzer. M. R.: Siegfried. L. C.: Kaden. T. A. Inorg. Chint Acta 1996. $2+6.41$.

23. Lindoy. L. F. The Chemisny of Hacocyclic Ligand Conplexes. Cambridge University Press: Cambridge. 1989 and references cited therein. 